\title{
The Effect of Leverage, Sales Growth, Cash Flow on Financial Distress with Corporate Governance as a Moderating Variable
}

\author{
Rizka Vidya Dwi Giarto*1 and Fachrurrozie ${ }^{2}$ \\ 1,2 Accounting Department, Faculty of Economics, Universitas Negeri Semarang
}

\section{ARTICLE INFO}

\section{Article History:}

Received January $15^{\text {th }}, 2020$

Accepted March $3^{\text {th }}, 2020$

Available March 30 $0^{\text {th }}, 2020$

\section{Keywords:}

financial distress; corporate governance; leverage; sales growth; and cash flow

\begin{abstract}
The aim of this study is to detect the effect of leverage, sales growth, and cash flow on financial distress with corporate governance as moderating variable. This research used all of basic and chemical sector manufacturing companies listed on the Indonesian Stock Exchange (IDX 2013-2017 period, there were 69 companies. Sampling used with purposive sampling technique and selected 31 companies with 152 analysis units. The data was analysed by descriptive statistical analysis and logistic regression for inferential statistical. The Results show that leverage has significant positive effect to financial distress. Sales growth has no significant effect to financial distress. Cash flow has a significant negative effect to financial distress. Corporate governance measured by managerial ownership is be able to weaken the positive effect of leverage and strengthen the negative effect of sales growth to financial distress, but not be able to strengthen the negative effect of cash flow to financial distress. The conclusions in this research are just leverage and cash flow have significantly effect to financial distress, as well as corporate governance only able to moderate the effect of leverage and sales growth to financial distress.
\end{abstract}

(C) 2020 Published by UNNES. This is an open access article under the CC BY license (http://creativecommons.org/licenses/by/4.0/)

\section{INTRODUCTION}

Global economic conditions which are weakening cause economic growth in Indonesia to decline. This can affect corporate activities and performance which can cause the company to be unable to maintain its business amid increasingly fierce business competition. During 2013 to 2017, at least 19 companies were forced to leave the Indonesia Stock Exchange (IDX). Most of the company's delisting is due to bankruptcy.

Examples of companies that are delisted due to bankruptcy are PT Surya Agung Industri Pulp and Kertas Tbk (SAIP) \& PT Asia Paper Mills. PT Surya Agung Industri Pulp and Kertas Tbk suffered a loss of Rp162,819,642,564 in 2012 and had a debt of US \$ 415,035 , thus declared bankrupt and delisted from IDX. In the same case, the Jakarta Commercial Court declared the bankruptcy of PT Asia Paper Mills on August 7, 2017 due to its inability to pay its debts which reached Rp568 billion (Sari, 2017).

If we look closely, before going bankrupt a company will experience financial distress. Platt \& Platt

\footnotetext{
*E-mail: rizkavidya3@gmail.com

_Address: L2 Building 2nd floor, Campus Sekaran, Gunungpati, Semarang, Indonesia, 50229
}

(2002) said financial distress is a state before bankruptcy or when corporate financial condition is decreasing which is marked by the inability of the company to pay off its obligations to creditors. An early warning signal that a company will experience bankruptcy can be through prediction of financial distress, so the company can immediately improve its condition to a stable state.

According to the Central Bureau of Statistics in one of the sub-sectors of manufacturing companies namely chemical and chemical goods companies experienced a financial stress which was marked by a decrease in production of $3.57 \%$ in 2013 , it decreased by around $8.93 \%$ in 2015 and in 2017 down by $12.02 \%$. In the context of companies, financial distress occurs at a pulp \& paper sub-sector, namely PT Dwi Aneka Jaya Kemasindo Tbk (DAJK) in 2016. This was marked by a decrease in sales of up to $78.62 \%$ and total debt of Rp870.17 billion in 2016 (Astria, 2017). If this continues continuously and is left without any action to improve, then the company will have financial difficulties for its operational activities which will then go bankrupt.

Increased debt, decreased sales and profits indicate that financial distress is being experienced by the company. Based on these conditions, the company is required to manage the company by practicing a good ma- 
nagement to improve company performance. The better the company management creates better performance that is able to increase firm value. That way the probability of a company suffering from financial difficulties will be even smaller.

Financial distress can be influenced by various factors such as leverage, cash flow, sales growth, and managerial ownership have been widely studied by previous researchers. However, the previous research still shows inconsistency results. For example: Research conducted by Jaafar et al. (2018), Alifiah (2014), and Simanjuntak et al. (2017) show evidence that leverage is able to have a significant positive effect on financial distress. But different from the results of the research by Finishtya (2019) as well as Restianti \& Agustina (2018) which find result if leverage is not able to influence financial distress. Research by Nyamboga et al.(2014), Widhiari \& Merkusiwati (2015), as well as Yudiawati \& Indriani (2016) prove that sales growth can negatively affect financial distress. As with research by Jaafar et al. (2018) prove sales growth is not able to affect financial distress. Research conducted by Sayari \& Mugan (2013) as well as Fawzi et al.(2015) show evidence of cash flow is able to influence financial distress negatively and significant1y. However, it is contrary to research conducted by Saleh (2018) proves if financial distress is not able to be influenced by cash flow.

The purpose of this study is to provide empirical evidence of the effect of leverage, sales growth, and cash flow on financial distress with corporate governance measured by managerial ownership. Managerial ownership is a system of corporate governance that can control agency problems in a company as a moderating variable in the manufacturing companies with basic and chemicals sub-sectors listed on the Indonesia Stock Exchange in 2013-2017. Thus, the originality of this study is to add corporate governance variable as moderating variable with the aim of being able to give effect of strengthening and weakening. The selection of this moderating variable is based on the results of the previous studies concerning corporate governance on financial distress showing the consistency of results, including research conducted by Salloum et al. (2012), Md-rus et al. (2013), and Udin et al (2017) which find out that corporate governance is able to have a negative effect on financial distress. Furthermore, with the existence of corporate governance, it is expected that company management is able to increase corporate performance so that financial distress can be avoided by the company.

The basic theories used in this study include signaling theory, agency theory, and pecking order theory. Signaling theory is the theory underlying voluntary disclosure that management always wants to show good news to potential investors (Muflihah, 2017). Agency theory is a theory that discusses contractual ties between company owners and management, where company owner as principal and agent or management as company manager (Jensen \& Meckling, 1976). Meanwhile, pecking order theory explains that companies prefer internal funding compared to external funding (Cotei et al., 2014).
Leverage shows the extent to which corporate operational activities are financed by debt. Based on pecking order theory, the higher the leverage ratio, the greater the risk of the company not being able to pay off its obligations. This indicates corporate financial performance is bad or financial distress that can make firm value go down.

Research results by Simanjuntak et al. (2017), Jiming \& Weiwei (2011) and Jaafar et al. (2018) show evidence that leverage variable has a significant positive effect on financial distress. This means the higher the leverage, the greater the company's probability of being in a financial distress situation.

\section{$\mathrm{H}_{1}$ : Leverage has a positive effect on financial dis- tress.}

Sales growth is the ratio that shows an increase / decrease in sales in a particular year at a company. In accordance with signaling theory, the steps taken by management will be used as a guide for capital owners to assess the company's opportunities in the future. High sales growth experienced by the company illustrates that the company has good performance and opportunities in the future. This will convey a positive signal for the owners of capital to invest their funds in the company. Conversely, if low/negative sales growth is experienced by the company, the company's performance is not good, so it will send a negative signal to investors.

Research by Nyamboga et al.(2014), Yudiawati \& Indriani (2016) as well as Widhiari \& Merkusiwati (2015) find sales growth is able to affect financial distress negatively significantly. This means the increased level of sales growth, increasing the profits obtained which can be used for company needs such as reducing lending funds to creditors to finance company activities. In other words, high income and profit indicate the company is not in a bad economic situation so that the financial distress condition can be avoided by the company.

\section{$\mathrm{H}_{2}$ : Sales growth has a negative effect on financial distress}

Cash flow is one of the indicators of a company's financial performance, especially operating cash flow. Cash flow of operating activity shows the large amount of cash obtained and used by the company from its operations. According to signaling theory, the company provides cash from high operating activities. This means the company has the ability internally from operating activity cash to pay off obligations without having to make loans from other parties and this is categorized as a positive signal. Conversely, if the company gets cash flow from low operating activities, the company has not been able to meet the internal needs of operating cash, and this is categorized as a negative signal.

Research of Julius (2017), Fawzi et al.(2015) and Yelkenci (2017) found evidence of cash flow of operating activity can negatively and significantly affect financial distress. This means if the cash flow from operating activities increases, the smaller the probability the company suffers from financial distress. Conversely, the less operating cash flow, the greater the probability of finan- 
cial distress experienced by the company.

\section{$\mathrm{H}_{3}$ : Cash flow has a negative effect on financial distress}

Reducing the opportunity for companies experience financial distress may use managerial ownership. In agency theory, agents have an important role for corporate survival. Agent's decision in funding is very important, if management chooses more funding from third parties, it will create more debt which can make the company vulnerable to financial distress.

The existence of management share ownership in a company will make management more tries to improve performance to be good so that the company can pay off its debts. Managerial ownership will make management take funding decisions well, where company management is more careful and selective in debt by choosing funding from friendlier debt or debt with the lowest interest rates. With a lower interest rate, the company will not face the risk of having difficulty paying its debts. Thus, the state of financial distress can be avoided by the companies.

\section{$\mathrm{H}_{4}$ : Corporate governance is able to weaken the positive effect of leverage on financial distress.}

Financial distress can be avoided if the company is able to make performance improvements, one of which is by providing managerial ownership. In agency theory, the decision of corporate management is made by agent, that is management. Management decides strategies that can be used to increase sales. Thus, the increase in sales will reduce the opportunity for companies to suffer financial distress.

The existence of corporate governance that is estimated by managerial ownership, then management will act as manager of the company and act as shareholders together so that the decisions taken by management will be felt its benefit by the management. It is expected that management can improve corporate performance by implementing strategies to increase sales and reduce corporate operating expenses. Thus, the company will have high profits that reflect the company has good performance and produce good financial information. With good performance owned by the company, the probability of the company suffering from financial distress will be smaller.

\section{$\mathrm{H}_{5}$ : Corporate governance is able to strengthen the negative effect of sales growth on financial dis- tress.}

Corporate agency conflict can be reduced by managerial ownership. According to agency theory, managerial share ownership can reduce the probability of financial distress that can be experienced by the company. Cash flow of small operating activities owned by the company or even negative tends to be fast to experience financial distress. However, with the presence of corporate governance that is estimated by managerial ownership, management is expected to be able to improve corporate performance.

Managerial ownership plays an important role in influencing cash flow on financial distress. Management as a manager as well as a shareholder will improve the cash management performance of the company's operating activities better. Management will conduct the effectiveness and efficiency of cash flows from operating activities where management conducts regular cash flow of operating activity. Therefore, the company will not have idle funds in cash and will get enough cash to meet the needs of the company. A good management of operating cash flow will generate cash flow from operating activities which is high so it can minimize the opportunity for financial distress to occur in the company.

\section{$\mathrm{H}_{6}$ : Corporate governance is able to strengthen the negative effect of cash flow on financial distress}

\section{RESEARCH METHODS}

This research was included in quantitative research with causality hypothesis study. Secondary data were collected using documentation technique used as data in this study. All basic and chemical sub sectormanufacturing companies listed on the Indonesia Stock Exchange in 2013-2017 were used in the study. The companies were chosen as the object of research because the basic and chemical sub-sector manufacturing industry is a company producing basic materials used by other companies. The economic condition of this company sector needs to be considered so as not to cause overall economic activity is hampered. Sampling technique used purposive sampling technique.

Table 1. Total Sample

\begin{tabular}{ccc}
\hline Information & $\begin{array}{l}\text { Beyond } \\
\text { Criteria }\end{array}$ & Criteria \\
\hline
\end{tabular}

Basic and chemical industrial sector manufacturing companies listed on the IDX

Companies that publish complete financial statements for the period 2013-2017

Companies that have managerial ownership

Total Sample

(29)

Total research data 2013-2017 (31 x 5 years)

Outlier data

Number of Analysis Units

Source: Secondary data processed (2019)

Financial distress was used as the dependent variable. The independent variable consists of leverage, sales growth, and cash flow. The last is corporate governance as a moderating variable.

The acquisition of research data derived from corporate annual financial statements and with testing conducted using descriptive statistical analysis method and inferential statistical analysis using IBM SPSS Statistics 24. Inferential statistical analysis used logistic regression and absolute difference test value analysis for modera- 
Table 2. Variable Definition and Measurement

\begin{tabular}{|c|c|c|}
\hline Variables & Operational Definition & Measurement \\
\hline $\begin{array}{l}\text { Financial Distress } \\
\text { (FD) }\end{array}$ & $\begin{array}{l}\text { Circumstances before bankruptcy or liquidation where } \\
\text { financial conditions decline (Platt \& Platt, 2002) }\end{array}$ & 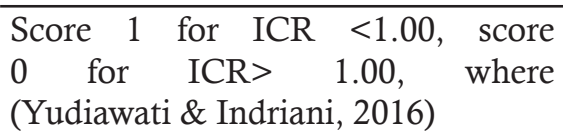 \\
\hline Leverage (FLEV) & $\begin{array}{l}\text { A ratio that measures how much a company uses debt } \\
\text { for its business activities. (Ong et al., 2017) }\end{array}$ & (Daniel \& Ionut, 2013) \\
\hline Sales growth $(\mathrm{PP})$ & $\begin{array}{l}\text { This ratio measures the increase in the level of sales in } \\
\text { a period. (Widhiari \& Merkusiwati, 2015) }\end{array}$ & (Jaafar et al., 2018) \\
\hline Cash Flow (AK) & $\begin{array}{l}\text { Changes in the amount of cash that occurs in a com- } \\
\text { pany during a certain period (Julius, 2017) }\end{array}$ & (Julius, 2017) \\
\hline $\begin{array}{l}\text { Corporate Gover- } \\
\text { nance }(\mathrm{CG})\end{array}$ & $\begin{array}{l}\text { The process or system of management, direction, and } \\
\text { control in a company that is influenced by legislative, } \\
\text { regulatory, legal, market mechanism, and the efforts of } \\
\text { all participants (Haq et al., 2016) }\end{array}$ & (Udin et al., 2017) \\
\hline
\end{tabular}

Source: Various sources

ting variable with a level of $\alpha=0.05$. This study used a regression model that can be formulated in the equation:

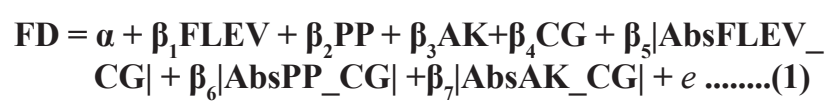

\section{RESULTS AND DISCUSSIONS}

Through descriptive statistical tests can be obtained the minimum, maximum, and mean values of each variable. Leverage gets a minimum value of 0.37 , a maximum of 2.767, and a mean of 0.60771 . Sales growth has a minimum value of -0.954 , a maximum of 1.990 and a mean of 0.03374 . Cash flow variable gets a minimum value of -0.291 , a maximum value of 0.799 and a mean of 0.04212 . As well as a minimum value of 0.000 , a maximum value of 0.840 and a mean of 0.08558 owned by corporate governance.

The regression model of the study does not show any indication of multicollinearity because between independent variable there is no that has a correlation coefficient above 0.90 . In addition, the result of statistical test on the feasibility of the model show that the model is fit with data step 0 of 204.757, and step 1 of 163.204 so that between step 0 and 1 decreased by 41.553 . The significance value of the probability of 0.095 also shows that the regression model is good and can be used. Negelkerke $\mathrm{R}^{2}$ shows that the dependent variable can be explained by the independent variable at
$32.3 \%$. The regression model is able to estimate financial distress of $74.3 \%$ occurring in the samples based on the classification table. After going through a descriptive statistical test and a model feasibility test, a hypothesis test of independent variable is performed on the dependent variable.

\section{The Effect of Leverage on Financial Distress}

Leverage is able to have a positive significant effect on financial distress. The result of this study is in line with pecking order theory which states that a decline in the value of a company is due to high leverage which results in a greater risk company suffering financial difficulties. Assets smaller than the debt owned by the company shows that most of the company's activities are financed by debt. High funding through debt that is not accompanied by an increase in income will make the company having trouble in paying debt and interest. Thus, the higher the leverage, the greater the risk of the company's inability to pay off debt so that the company will get closer to difficult financial conditions.

This research is in line with research conducted by Keener (2013), Jaafar et al.(2018) and Simanjuntak et al.(2017) where they stated that leverage is able to affect financial distress positively. This means that the higher the leverage ratio of a company, the greater the probability that a company will experience financial distress. Conversely, the smaller the leverage ratio, the smaller

Table 3. Hypothesis Test Results

\begin{tabular}{clccc}
\hline No. & \multicolumn{1}{c}{ Hypothesis } & B & Sig. & Results \\
\hline 1 & $\mathrm{H}_{1}$ : Leverage has a positive effect on financial distress & 1.718 & 0.000 & Accepted \\
2 & $\mathrm{H}_{2}$ : Sales growth has a negative effect on financial distress & -0.323 & 0.176 & Rejected \\
3 & $\mathrm{H}_{3}$ : Cash flow has a negative effect on financial distress & -0.604 & 0.025 & Accepted \\
4 & $\mathrm{H}_{4}$ : Corporate governance is able to weaken the positive effect of leverage on & 1.237 & 0.027 & Accepted \\
& financial distress & & & \\
5 & $\mathrm{H}_{5}$ : Corporate governance is able to strengthen the negative effect of sales & -0.605 & 0.050 & Accepted \\
& growth on financial distress & & & \\
6 & $\mathrm{H}_{6}$ : Corporate governance is able to strengthen the negative effect of cash flow & 0.383 & 0.187 & Rejected \\
& on financial distress
\end{tabular}


the probability of a company suffering financial distress.

\section{The Effect of Sales Growth on Financial Distress}

Sales growth is not able to affect financial distress. The result of this study is not in accordance with signaling theory, management steps for companies can provide guidelines for investors to see the opportunities of the company in the future. The companies with increased sales will convey a positive signal to potential investors that they have good performance and opportunities in the future. Therefore, it can be taken into consideration by investors to decide to invest funds in the companies.

There are two reasons behind the sales growth that cannot affect financial distress. First, a company can have high sales growth but it can also be followed by high growth in cost of goods sold so that producing low profits. Therefore, sales growth has not been able to prevent the companies from the condition of financial difficulties.

Secondly, company management may do earnings management. With certain methods, management can do earnings management to enhance financial statements. This makes the sales and profits listed in the company's financial statements do not always describe the real situation of the company. Management just wants to show that the company has a good performance that can be used to attract potential investors to invest in the company. Thus, the rise or fall in sales levels cannot be a reference for companies suffering from financial distress. Both of these reasons cause sales growth is not able to affect financial distress. The result of the study is in line with the findings by Julius (2017) and Jaafar et al.(2018) who proved the ratio of sales growth cannot affect financial distress.

\section{Effect of Cash Flow on Financial Distress}

Financial distress can be negatively affected by cash flow. The operating cash flow ratio is used to measure cash flow. This ratio shows the cash flow management carried out by the company in operating activities. According to signal theory states that high income of operating activity cash flow illustrates that the company is able to get cash to meet internally to meet the needs without making loans from outside, it is categorized as a positive signal. Conversely, if the operating activity cash flow of the company is low, it means that the company cannot manifest adequate cash and has poor performance, this will convey a negative signal to investors and creditors.

This finding is in accordance with research conducted by Sayari \& Mugan (2013), Fawzi et al.(2015), and Julius (2017) which prove the cash flow of operating activities negatively significantly affects financial distress. The higher the operating cash flow, the probability of the company suffering from financial distress is getting smaller. On the contrary, the lower the cash flow ratio of operating activities generated, the greater the probability that the company will suffer financial distress. The operating activity cash flow obtained by the company which is higher, indicating that the company has a good performance that is able to manage cash to meet the company's internal needs so that the smaller the probability of the company suffering financial distress.

\section{The Effect of Leverage on Financial Distress with Corporate Governance as Moderator}

The positive effect of leverage on financial distress can be weakened by corporate governance. Corporate governance is a process or system used in the management, direction and control of companies that are influenced by legislative, regulatory, legal, market mechanisms, and efforts of all participants (Haq et al., 2016). The corporate governance of this study is estimated by managerial shareholding.

Based on agency theory, it has been stated earlier that agents play an important role in the survival of the company and have the authority to make corporate decisions (Mafiroh \& Triyono, 2016). When shares owned by managerial companies are high, management will endeavour to create efficient performance in the company and can dominate the funding decision-making in the company.

The amount of share ownership by management will make management make funding decisions wisely. Management is more selective in conducting debt by choosing funding from debt with lower interest rates. With a small interest rate, it reduces the risk of the company's inability to pay its debts. The company's ability to pay debts will reduce the probability of financial distress to occur in the company.

\section{The Effect of Sales Growth on Financial Distress with Corporate Governance as Moderator}

The negative effect of sales growth on financial distress can be strengthened by corporate governance. In this study, corporate governance is measured by managerial ownership. Managerial shareholding is expected to improve corporate performance with sales that increase each year so as to achieve high profits. With sales and high profits, financial distress can be avoided by the companies.

The result of the research is in line with agency theory, where agents have the authority to make corporate decisions. Management as an agent decides the strategy used by the company to increase sales levels. With the presence of managerial ownership, management will act and make decisions not only for the interests of management but also for the interests of the company, because the benefits derived from decision making will also be felt by the management both beneficial or detrimental. High managerial ownership will make the management keeps trying to increase the firm value by increasing sales each year and reducing the company's operating costs. If sales increase, the company is able to meet its operational needs, then the occurrence of financial distress can be minimized. 


\section{The Effect of Cash Flow on Financial Distress with Corporate Governance as a Moderator}

Corporate governance is not able to strengthen the negative relationship of cash flow to financial distress. Managerial ownership is used as a measure of corporate governance in the research. This research contradicts agency theory which states that agency conflict can be reduced by managerial ownership so that financial distress can be avoided by companies.

Management ownership makes the management as manager and also shareholder must continue to improve company performance. Large managerial shareholding will make the management focus on improving the company's performance, through good corporate cash management to meet the operational needs and meet the obligations, so that the company will be avioded from financial distress.

Managerial ownership in this study is still relatively small, with an average of 0.08558 or 8.5 percent of shares outstanding. Thus, it has not been able to motivate the management to manage cash well to minimize the probability of companies suffering from financial distress. Some management will increasingly prioritize their own benefits compared to the prosperity of the company owner. The decision taken by the company's management must also consider the opinions of other shareholders. With little managerial ownership, the management has not been able to have fully the control to control the management of the company's cash flow so this cannot reduce the possibility of financial distress.

\section{CONCLUSIONS}

This study analyzes the effect of leverage, sales growth, and cash flow on financial distress with corporate governance as a moderating variable. The result shows that the higher the leverage will increase the probability of the company suffering financial distress, while the higher the ratio of cash flows from the company's operations, the probability of the company to suffer financial distress is increasingly reduced. In addition, sales growth is not able to affect financial distress. In addition, corporate governance can weaken the effect of leverage and strengthen the effect of sales growth on financial distress, but corporate governance has not been able to give the effect of cash flow on financial distress. In addition, sales growth is not able to affect financial distress. In addition, corporate governance can weaken the influence of leverage and strengthen the effect of sales growth on financial distress, but corporate governance has not been able to provide the effect of cash flow on financial distress.

The better the management of the company will be able to minimize the company experiencing financial distress. The greater managerial ownership in a company will motivate management to improve company performance further. This will lead the company to avoid from financial difficulties. Therefore, the presence of managerial ownership as a measure of corporate governance is able to affect leverage and sales growth on financial distress.
This study is limited to examining manufacturing companies in the basic and chemical sub-sectors. Thus, the next research is suggested to use a different sector, because financial distress can be suffered by all levels of the company if the company's performance gets worse. Another reason is to use other corporate governance variables for research moderation variables. This is due to one of the corporate governance variables namely managerial ownership in this study proven to have a strong or weak influence of the independent variable on the dependent variable, so it is assumed that other corporate governance variables might have an effect on financial distress.

\section{REFERENCES}

Alifiah, M. N. (2014). Prediction of financial distress companies in the trading and services sector in Malaysia using macroeconomic variables. Procedia - Social and Behavioral Sciences, 129, 90-98. https://doi.org/10.1016/j. sbspro.2014.03.652

Astria, R. (2017). Meski Penjualan Merosot, Rugi Dwi Aneka (DAJK) Turun 16,64\%. Retrieved February 6, 2019, from https://m.bisnis.com/market. read.20170403/192/642158/meski-penjualan-merosot-rugi-dwi-aneka-dajk-turun-1664

Cotei, C., Farhat, J., Abugri, B. A., Cotei, C., \& Farhat, J. (2014). Testing trade-off and pecking order models of capital structure: does legal system matter? Managerial Finance, 37(8), 715-735. https://doi. org/10.1108/03074351111146193

Daniel, B., \& Ionut, G. (2013). Prediction Of Corporate Bankruptcy In Romania Through The Use Of Logistic Regression. Annals of Faculty Economics, 1(1), 976-986.

Fawzi, N. S., Kamaluddin, A., \& Mohd, Z. (2015). Monitoring Distressed Companies through Cash Flow Analysis. Procedia Economics and Finance, 28(April), 136-144. https://doi.org/10.1016/S2212-5671(15)01092-8

Finishtya, F. C. (2019). The Role of Cash Flow of Opea rational, Profitability, And Financial Leverage in Predicting Financial Distress On Manufacturing Company In Indonesia. Journal of Applied Manajement (JAM), 17(1), 110-117.

Haq, A. Q., Rikumahu, B., \& Firli, A. (2016). Pengaruh Karakteristik Praktik Corporate Governance Terhadap Prediksi Financial Distress. Jurnal Profit, 3(1), 9-20.

Jaafar, M. N., Muhamat, A. A., Faigah, S., Alwi, S., Karim, N. A., \& Rahman, S. A. (2018). Determinants of Financial Distress among the Companies Practise Note 17 Listed in Bursa Malaysia Determinants of Financial Distress among the Companies Practise Note 17 Listed in Bursa Malaysia. International Journal Of Academic Research In Business \& Social Sciences, 8(11), 800-811. https://doi.org/10.6007/IJARBSS/v8-i11/4956

Jensen, M. C., \& Meckling, W. H. (1976). Theory of the Firm : Managerial Behavior, Agency Costs and Ownership Structure Theory of the Firm: Managerial Behavior , Agency Costs and Ownership Structure. Journal Of Financial Economics, 3(4), 305-360.

Jiming, L., \& Weiwei, D. (2011). An Empirical Study on the Corporate Financial Distress Prediction Based on Logistic Model : Evidence from China's Manufacturing Industry. International Journal of Digital Content Technology and Its Applications, 5(6), 368-379. https://doi. org/10.4156/jdcta.vol5.issue6.44

Julius, F. (2017). Pengaruh Financial Leverage, Firm Growth, 
Laba Dan Arus Kas Terhadap Financial Distress. JOM Fekon, 4(1), 1164-1178.

Keener, M. H. (2013). Predicting The Financial Failure Of Retail Companies In The United States. Journal of Business \& Economics Research, 11(8), 373-380.

Mafiroh, A., \& Triyono, T. (2016). Pengaruh Kinerja Keuangan Dan Mekanisme Corporate Governance Terhadap Financial Distress. Riset Akuntansi Dan Keuangan Indonesia, 1(1), 46. https://doi.org/10.23917/reaksi. v1i1.1956

Md-rus, R., Nisham, K., Mohd, T., Latif, R. A., \& Alassan, Z. N. (2013). Ownership Structure and Financial Distress. Journal of Advanced Management Science, 1(4), 363-367. https://doi.org/10.12720/joams.1.4.363-367

Muflihah, I. Z. (2017). Analisis Financial DIstress Perusahaan Manufaktur Di Indonesia dengan Regresi Logistik. Majalah Ekonomi, 22(2), 254-269.

Nyamboga, T. O., Omwario, B. N., Muriuki, A. M., \& Gongera, P. G. (2014). Determinants of Corporate Financial Distress : Case of Non- Financial Firms Listed in the Nairobi Securities Exchange. Research Journal Of Finance And Accounting, 5(12), 193-207.

Ong, J. B., Muturi, W., Oluoch, O., \& Karanja, J. N. (2017). Leverage as Financial Antecedent to Financial Distress among Listed Companies at Nairobi Securities Exchange. Journal of Emerging Issue in Economics, Finance and Banking (JEIEFB), 8(6), 95-104.

Platt, H. D., \& Platt, M. B. (2002). Predicting Corporate Financial Distress : Reflections on Choice-Based Sample Bias. Journal of Economics and Finance, 26(2), 184-199.

Restianti, T., \& Agustina, L. (2018). The Effect of Financial Ratios on Financial Distress Conditions in Sub Industrial Sector Company. Accounting Analysis Journal, 7(1), 25-33. https://doi.org/10.15294/aaj.v5i3.18996

Saleh, D. S. (2018). Pengaruh Operating Capacity, Arus Kas Operasi dan Biaya Variabel Terhadap Financial Distress Pada Perusahaan Manufaktur Subsektor Textil dan Garment yang Terdaftar Di Bursa Efek Indonesia
(BEI) Tahun 2009-2016. E-Qien Jurnal Ekonomi Dan Bisnis, 8(1), 34-49.

Salloum, C., Schmitt, C., \& Bouri, E. (2012). " Does board structure affect financial distress? A Study with reference to family firms in Lebanon " Does board structure affect financial distress? A study with reference to family firms in Lebanon. Investment Management and Financial Innovations, 9(4), 112-123.

Sari, D. P. (2017). Ini Daftar Perusahaan Yang Pailit Sepanjang 2017. Retrieved February 6, 2019, from https://m. bisnis.com/kabar24/read/20171228/16/721762/inidaftar-perusahaan-yang-pailit-sepanjang-2017

Sayari, N., \& Mugan, F. N. C. S. (2013). Cash Flow Statement as an Evidence for Financial Distress. Universal Journal of Accounting and Finance, 1(3), 95-103. https://doi. org/10.13189/ujaf.2013.010302

Simanjuntak, C., Titik, F., \& Aminah, W. (2017). Pengaruh Rasio Keuangan Terhadap Financial Distress ( Studi Pada Perusahaan Transportasi Yang Terdaftar Di Bursa Efek Indonesia. E-Proceeding of Management, ISSN : 2355-9357, 4(2), 1580-1587. https://doi.org/2355-9357

Udin, S., Khan, M. A., \& Javid, A. Y. (2017). The Effects of Ownership Structure on likelihood of Financial Distress : An Empirical Evidence. International Journal of Business Society, 1-36. https://doi.org/https://doi. org/10.1108/CG-03-2016-0067

Widhiari, N. L. M. A., \& Merkusiwati, N. K. L. A. (2015). Pengaruh Rasio Likuiditas, Leverage, Operating Capacity, Dan Sales Growth Terhadap Financial Distress. E-Jurnal Akuntansi Universitas Udayana, 2(11), 456-469.

Yelkenci, I. O. O. T. (2017). A Theoretical Approach to Financial Distress Prediction Modeling. Managerial Finance, 43(2), 1-21.

Yudiawati, R., \& Indriani, A. (2016). Analisis Pengaruh Current Ratio, Debt To Total Asset Ratio, Total Asset Turnover, Dan Sales Growth Ratio Terhadap Kondisi Financial Distress. Diponegoro Journal of Management, $5(2), 1-13$. 